(C) Group of autors, 2016

UDC 616.71-007.234:576.5:636

DOI - http://dx.doi.org/10.14300/mnnc.2016.11034

ISSN - 2073-8137

\title{
NEURAL CREST-RELATED STEM CELLS OF ORAL ORIGINS IN VITRO AND USED IN OSTEOPOROTIC SHEEP MODEL FOR BEING INVESTIGATED DUE TO THERAPEUTIC EFFECTS IN ALVEOLAR BONE REGENERATION
}

Grimm W.-D. ${ }^{1,}$, , Fritsch T. ${ }^{3}$, Giesenhagen B. ${ }^{4}$, Sirak S. V. ${ }^{1}$, Sletov A. A. ${ }^{1}$, Aybazov M. M. ${ }^{5}$, Tebyakina S. V. ${ }^{1}$, Shchetinin E. V. ${ }^{1}$, Vukovic M. A. ${ }^{6}$, Koshel I. V. ${ }^{1}$, Sirak A. G. ${ }^{1}$, Petrosyan G. G. ${ }^{1}$, Adamchik A. A. ${ }^{7}$

1 Stavropol State Medical University, Russian Federation

2 Witten/Herdecke University, Witten, Germany

3 University of Arad, Arad, Romania

4 University of Frankfurt/M., Frankfurt am Main, Germany

${ }^{5}$ All-Russia Research Institute of Sheep and Goat, Stavropol, Russian Federation

${ }^{6}$ Praxisteam Hasslinghausen, Germany

7 Kuban State Medical University, Krasnodar, Russian Federation

\section{ИСПОАЬЗОВАНИЕ ЭКТОМЕЗЕНХИМААЬНЫХ СТВОАОВЫХ КАЕТОК А^Я ПОТЕНЦИРОВАНИЯ РЕГЕНЕРАЦИИ ААЬВЕОАЯРНОЙ КОСТИ НА МОАЕАИ ОСТЕОПОРОЗА У ОВЕЦ}

\author{
В.-А. Гримм ${ }^{1,2}$, Т. Фрич ${ }^{3}$, Б. Гизенхаген ${ }^{4}$, С. В. Сирак ${ }^{1}$, А. А. Слетов ${ }^{1}$, М. М. Айбазов ${ }^{5}$, \\ С. В. Тебякина' ${ }^{1}$, Е. В. Щетинин ${ }^{1}$, М. А. Вукович ${ }^{6}$, И. В. Кошель ${ }^{1}$, А. Г. Сирак' ${ }^{1}$, \\ Г. Г. Петросян ${ }^{1}$, А. А. ААамчик ${ }^{7}$ \\ ${ }^{1}$ Ставропольский госуАарственный меАицинский университет, Российская ФеАерация \\ 2 Университет Виттен - ХерАекке, Виттен, Германия \\ 3 Университет АраА, АраА, Румыния \\ 4 Университет Франкфурта-на-Майне, Франкфурт-на-Майне, Германия \\ 5 Всероссийский НИИ овцевоАства и козовоАства, СтавропоАь, Российская ФеАерация \\ ${ }^{6}$ Praxisteam Hasslinghausen, Германия \\ 7 Кубанский госуАарственный МеАицинский университет, КрасноАар, \\ Российская ФеАерация
}

Neural crest-related stem cells (NCSC) have great promise in the field of regenerative medicine due to their differentiation potential into several lineages. Besides the periodontium, and root surfaces of extracted teeth, NCSC can be obtained from the palate, which represents a large stem cell reservoir in the mucosa. Osteoporotic Sheep provide an appropriate large animal model for preclinical studies. In this initial study, we focused on approving the Osteoporotic Sheep Model, the isolation and characterization of NCSC from osteoporotic sheep palate as an alternative to other stem cell sources and on appropriate X-ray and histological methods for evaluation of the alveolar bone regeneration process. Primary ovine neural crest-related stem cells were obtained from the palate for comparison with human derived NCSC. The cultured ovine NCSC, which were sorted by different methods of characterization were examined for morphology, proliferation and bone-regenerative activity in our osteoporotic sheep model. Density expression of alveolar bone was measured by using CT images. Osteogenic potentials of ovine NCSCs were evaluated by different histological measurements on non-demineralized and demineralized alveolar bone tissues. The in vitro cell assays demonstrated the osteoinductive potential of ovine NCSC as typical sphere-forming pure stem cell culture and its proliferation, and differentiation as well as initial bone formation in a large-animal model. The different histological measurements on non-demineralized and demineralized alveolar bone tissues used in our proof of principle study have showed a high potential for evaluating the regenerative bone processes taking place in our Osteoporotic Sheep Model. Based on these findings, ovine NCSC might serve as an appropriate alternative cell source in pre-clinical research using a large animal model for evaluating the regenerative bone processes taking place in the Osteoporotic Sheep Model developed by our interdisciplinary and international research group.

Key words: NCSC, osteoporotic sheep model, CT, 3D-reconstruction, density measurements, histological analysis, stem cell

Эктомезенхимальные стволовые клетки (ЭМСК) имеют высокий потенциал дифференцировки. Классическим источником NCSC остаются периодонт и пульпа зуба. Учитывая значительную клиническую значимость в применении принципов регенеративной медицины при остеопорозе челюстных костей, представлялось ин- 
тересным обосновать использование альтернативного источника стволовых клеток, полученных из слизистой оболочки нёба на модели остеопороза у баранов. Проведены культуральные методы получения, выделения, характеристики, морфологии ЭМСК. Анализ прогенеторного потенциала ЭМСК на модели остеопороза челюстных костей у баранов компьютерными, гистологическими и морфометрическими методами показал существенный остеоиндуктивный потенциал изучаемых клеток. Проведенное исследование показало, что мягкое нёбо может служить альтернативным источником ЭМСК для проведения доклинических исследований с применением модели остеопороза у крупных животных.

Ключевые слова: эктомезенхимальные стволовые клетки, модель остеопороза у овец, КT, 3D-анализ, денситометрия, гистологический анализ

\section{T} he human oral cavity contains various adult stem cell populations able to perform self-renewal, multi-lineage differentiation and to contribute to dental regeneration. Among others, stem cells have been described within the dental follicle (dental follicle stem cells, DFC) [8], periodontal ligament (periodontal ligament stem cells; PDLSC) [17] and in exfoliated deciduous teeth (stem cells from human exfoliated deciduous teeth; SHED) [13]. However, the definition and classification of such dental stem cells is a matter of ongoing scientific debate. While some reports classify them as ectomesenchymal stem cells, others define them as mesenchymal or neural crest-derived. Notably, dental stem cell populations and cranial NCSC show comparable odontogenic differentiation potential [2]. Further, the neural crest is embryonic origin of most dental cell types and surrounding tissues including odontoblasts, cementoblasts in addition to the dental pulp, the periodontium and the alveolar bone [14]. The developmental origin of the tooth has been spectacularly demonstrated by Mitsiadis in 2003 [15].

Based on these developmental evidences has been proposed a unifying classification of such dental stem cells that is based on their clearly demonstrated developmental origin and their broad multi-lineage differentiation potential (ectoderm and mesenchyme). Consequently, the term oral Neural Crest-Derived Stem Cells (oNCSC) is a new category that would include most adult dental stem cells described so far [3].

Bone grafting materials have extensively been used in the field of dentistry to fill bone defects caused by trauma, periodontal disease, infection, and a variety of biochemical and skeletal disorders. Over the years, the role of biomaterials has changed from a passive, structural supporting network to one that may provide and orchestrate the process of cell migration and/or differentiation down to a bone-forming lineage.

To optimize the osteoinductive potential of bone grafting materials, it was recently proposed that the osteoinduction phenomenon is divided into three principles. These include the ability for an osteoinductive material: 1) to recruit mesenchymal osteoprogenitor cells; 2) to induce an undifferentiated mesenchymal cell into a mature bone-forming osteoblast; 3 ) to induce ectopic bone formation when implanted in extraskeletal locations.

A profound knowledge on the biological differences and shared characteristics between the dental NCSC populations introduced above are critical for design and future application of regenerative alveolar bone therapies.

Previously conducted studies of our research group $[4,9]$ revealed that oNCSC are of ecto-mesenchymal origin and could be differentiated into the neural, respectively chondrocytic, periodontal and osteogenic lineage indicating multipotent stem cell characteristics.

oNCSC in combination with bone substitute materials may accelerate the augmentation of alveolar bone and perhaps, stem cell-based therapies can become an alternative to autologous, allogenic, or synthetic bone transplants and substitutes.

The aim of this study was to determine the osteoinductive potential of novel bone grafts using osteoporosis sheep bone defect model comparing for its ability to induce in vitro ovine NCSC recruitment, proliferation, and differentiation as well as ectopic bone formation in an large-animal model.

Material and Methods. Osteoporotic Sheep Model Two young female sheep with an average body weight of $30 \mathrm{~kg}$ has been used in this initial study (Fig. 1). Six months prior to the studies start, animals had been neutered by ovariectomy to induce osteoporosis. Changes in the microarchitecture of alveolar bone has been investigated through 3D tomography analysis and bone density measurements. Animal handling and surgical procedures has been conducted according to the European Community Guidelines for the care and use of laboratory animals (DE 86/609/CEE) and has been approved by the local ethical committee at the Stavropol State Medical University School (number $98 / 4$, of $10 / 03 / 2011$ ).

For our osteoporotic sheep model we have used the Stavropol breed (ST). For the immunogenetic and molecular genetic comparison of the Stavropol breed (ST) with other Caucasian sheep breeds DNA have taken [11]. Microsatellite analysis was performed on 11 loci identified in sheep (MsM42, OarFCB20, OarFCB11, MAF65, MsM527, OarCP49, OarAE119, HSC, MAF214) and cattle (TGLA53, INRA49).

To acquire sheep alveolar bone CT images, the CT conditions were the following: $293 \times 293 \times 100 \mu \mathrm{m}$ voxel size (virtually degraded resolution), temporal bone protocol, $120 \mathrm{kVp}, 300 \mathrm{mAs}, 150 \mathrm{~mm}$ field of view, $12 \mathrm{~mm}$ away from distal. Image segmentation has been applied to the acquired sheep alveolar bone CT images using Osiris XHD. Various regions window levels/widths (contrast) were applied to establish a clear separation between the cortical bone and the trabecular bone. The set up image segmentation has been performed with a contrast region on $300 / 2000$ for visualization, which was shown by coloring on the trabecular bone region for clear separation during 3D reconstruction. Also, automatic detection of each region has been performed, and then manual segmentation were performed as needed. The segmented images has been accumulated layer-by-layer following the Z-plane and reconstructed as a 3D image.

Subjects and Cell Culture of NCSCs Two young female osteoporotic sheep have served as the ovine palatal-derived crest-related stem cells (ovine NCSC) donors. Using minimal-invasive access to the palate the subepithelial tissue has been extracted. Tissues were digested to obtain single-cell suspensions of ovine NCSC. Primary cultures have been maintained in a-minimal essential medium in a humidified atmosphere $\left(37^{\circ} \mathrm{C}, 5 \% \mathrm{CO}_{2}\right)$.

Histological investigations The trephine burs with the bone biopsies inside were fixed in four per cent formalin 
for 5-7 days, rinsed in water and dehydrated in serial steps of ethanol $(70 \%, 80 \%, 90 \%, 100 \%)$, remaining for one day in each concentration.

Embedding in methylmethacrylate Technovit 9100 New is a polymethyl methacrylate (PMMA)-based technical resin.

The embedding procedure consists of four major steps: a general fixation and dehydration step; a pre infiltration step; an infiltration step; a polymerization step.

The polymerization process takes place at $4^{\circ} \mathrm{C}$ in an adjustable temperature refrigerator.

Preinfiltration After dehydration, the specimens were incubated light-protected for 3 days at $4 \mathrm{C}$ in the destabilized preinfiltration solution.

Infiltration The preinfiltration solution has been exchanged with the infiltration solution and then kept therein protected from light for 7 days at $4{ }^{\circ} \mathrm{C}$.

Polymerization After the infiltration procedure, the specimens were transferred from the embedding cassettes into special pre-cooled Teflon embedding molds and quickly covered with the final polymerization solution. The polymerization process takes place in a refrigerator with a controlled temperature of $4{ }^{\circ} \mathrm{C}$, the bottom of which is filled with silica gel to ensure low atmospheric humidity. After 3-5 days, the polymerization process was completed and the hardened blocks have been pressed out of the molds.

Sectioning and deacrylation The tissue blocks were sectioned at $5 \mu \mathrm{m}$ using a RM 2155 Microtome (Leica, Bensheim, Germany) using special size D carbide knives (Slee, Mainz, Germany).

Embedding in paraffin The isolated bone blocks has been fixed with $10 \%$ Neutral Buffered Formalin, decalcified in EDTA disodium salt, buffered $10 \%$ edetic acid $(\mathrm{pH} 8.0)$ and subjected to standard histological processing including paraffin-embedding technique. Sections have been deparaffinized and stained.

Stains Haematoxylin and eosin stain were done according to the standard procedure. For toluidine blue stain, rehydrated sections were incubated in $0.1 \%$ toluidine blue $\mathrm{O}$ for $20 \mathrm{~s}$, washed in distilled water, dehydrated in a graded series of ethanol and mounted in Eukitt.

Results and Discussion. In the present study, we have demonstrated that the ovine NCSCs are able to spontaneously increase the expression of bone markers suggesting that the auto-induction is likely governed by a process receiving much of its cues from surface topographical features and potential chemical signals from the dissolution of the scaffold material.

Single-cell suspensions derived from freshly digested subepithelial soft tissue have been incubated with blocking buffer on ice. Cells $\left(0.3\right.$ to $\left.1.0 \times 10^{6}\right)$ ovine NCSCs have been subsequently incubated with CD10 6 supernatant on ice. Cells were separated on a Magnetic Particle Concentrator and used for establishing primary cultures (Fig. 1)

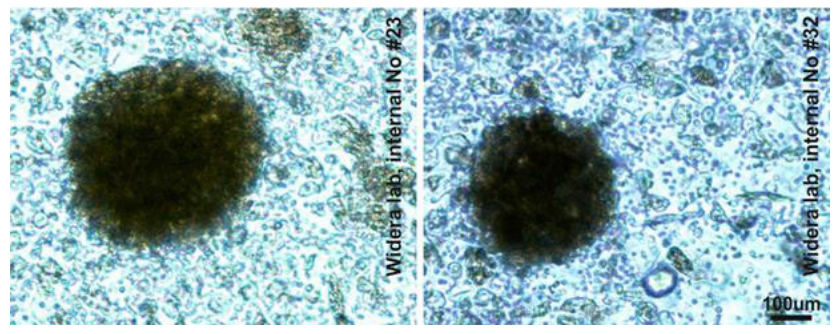

Fig. 1. Established primary cultures of ovine NCSC after 6 days (confocal microscopy, live-staining, 10 fold)
Typically classic stain (Fig. 2) in histological demineralized gross specimens showed connective tissue strands visible when detaching the periosteum.

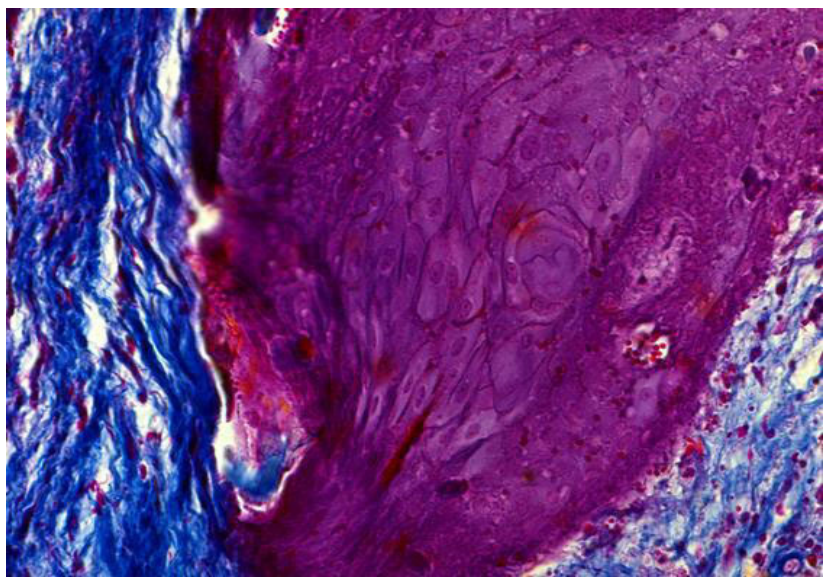

Fig. 2. Histological demineralized gross specimens connective tissue strands visible when detaching the periosteum (staining AlcianBlue, 10-fold)

Classic stain and microscopical techniques of a Technovit 9100 - embedded tooth/bone biopsy from the osteoporotic ovine lower jaw viewed with polarization optics are showing all details of regenerating woven bone (Fig. 3). The different layers of the biopsy can be clearly distinguished. Especially for bone tissues, polarization optics is an important tool with which to view the spatial organization of anisotropic structures like the collagen fibres in regenerating woven bone. The polarization optics is viewing the spatial organization of anisotropic structures like the collagen fibres in regenerating woven bone. Remarkably, in a higher resolution there was expression of mononuclear cells along the cementumperiodontium line suggesting an involvement in osteogenesis.

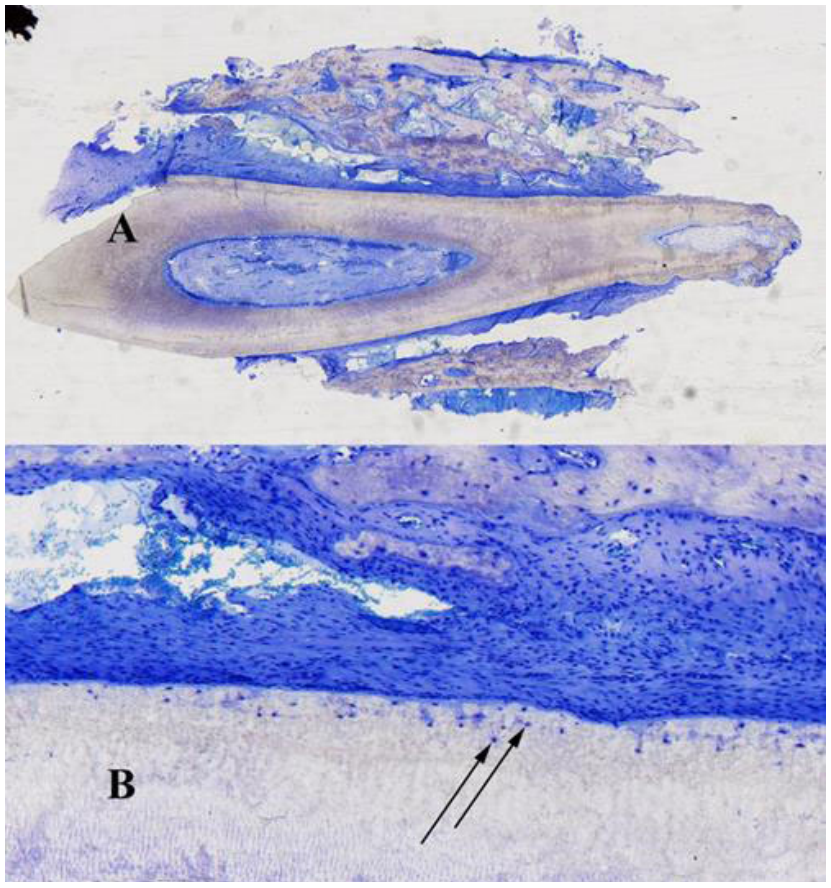

Fig. 3. (A) Ovine root tooth and ovine alveolar bone tissues of a «Technovit 9100 New-embedded» ovine jaw stained with toluidine blue, 5-fold. (B) In a higher resolution

(10-fold) there was expression of mononuclear cells along the cementum-periodontiumline (marked by arrows) suggesting an involvement in osteogenesis (using Axiovision) 
Our laboratory has previously demonstrated that oNCSC are able to release a wide-array of growth factors over time including bone morphogenetic proteins, transforming growth factors, insulin-like growth factors, and vascular endothelial growth factors [3]. Furthermore, it was recently demonstrated that the oNCSC are also able to release osteoblast-specific growth factors, which may further contribute to cell growth and bone regeneration [4]. We investigated the in vivo regenerative capacity of human-derived oNCSC in 10-week-old athymic nude rats as described early [22]. In particular, our research group has investigated whether human oNCSC could be differentiated into the osteogenic lineage and, if so, whether these cells are able to regenerate alveolar bone tissue in vivo in an athymic rat model.

In sum, our data clearly demonstrated that human oNCSC are capable to regenerate elements of bone in vivo. Our initial "proof of principle» study $[5,6,7]$ supports the hypothesis that HBA substitute materials is suitable for dental stem cell tissue engineering.

Human oNCSC can be transplanted in an autologous manner using human allogenic bone substitutes as carrier material, thus no immunosuppression is necessary and no possible graft-vs.-host disease will occur in treated patients [4]. Briefly, human oNCSC have been isolated from human palate previously harvested during minimal invasive periodontal surgery.

Furthermore, human oNCSCs can be cultured as "dentospheres», which is a further hallmark of stem cells $[1,21,22]$.

Conclusions. Several recent studies showed that NCSC can be isolated from mammalian cranio-facial tissues such as periodontal ligament and from human palate as shown by our research group [3, 21, 22], and by dental pulp as shown by our international research group [12].

\section{References}

1. Arnold W. H., Becher S., Dannan A. Morphological characterization of periodontium-derived human stem cells. Ann Anat. 2010;192(4):215-219.

2. Chen G., Sun Q., Xie L. Comparison of the Odontogenic Differentiation Potential of Dental Follicle, Dental Papilla, and Cranial Neural Crest Cells. J Endod. 2015;41:10911099.

3. Grimm W.-D., Giesenhagen B., Hakki S. S. Translational Research and Therapeutic Applications of Neural CrestDerived Stem Cells in Regenerative Periodontology. Curr Oral Health Rep. 2015.

4. Grimm W.-D., Dannan A., Becher S. et al. The ability of human periodontium-derived stem cells to regenerate periodontal tissues: a preliminary in vivo investigation. Int J Periodontics Restorative Dent. 2011;31(6):94-101.

5. Grimm W.-D., Plöger M., Schau I. Complex, threedimensional reconstruction of critical size defects following delayed implant placement using stem cellcontaining subepithelial connective tissue graft and allogenic human bone blocks for horizontal alveolar bone augmentation: A case report as proof of clinical study principles. Medical News of North Caucasus. 2014:9(2):131-133.

6. Grimm W.-D., Dannan A., Giesenhagen B. Translational Research: Palatal-derived Ecto-mesenchymal Stem Cells from Human Palate: A New Hope for Alveolar Bone and Cranio-Facial Bone Reconstruction. Int J Stem Cells. 2014;7(1):23-29.

7. Grimm W.-D., Plöger M., Schau I. Prefabricated 3D allogenic bone block in conjunction with stem cellcontaining subepithelial connective tissue graft for horizontal alveolar bone augmentation: A case report as proof of clinical study principles. Medical News of North Caucasus. 2014:9(2):175-178.

8. Handa K., Saito M., Yamauchi M. Cementum matrix formation in vivo by cultured dental follicle cells. Bone. 2002:31:606-611.
Despite the use of sheep as a large animal model for a wide range of applications in preclinical research [16, 18, $19,20]$, the characterization of ovine NCSC is still limited. This study describes the isolation and characterization of palate-derived ovine NCSC based on different cell surface markers and on typical sphere formation. These cells have in common that they form neurosphere-like clusters and proliferate in serum-free culture in the presence of FGF-2 and EGF. In light of these findings, the reason for this initial proof of principle study is the identification of these stem cells within the palate of our osteoporotic sheep model.

To decipher the developmental make-up of the alveolar and facial bone region, we have followed the path of the migratory neural crest, the neural crest lineage segregation as a blueprint for bone regeneration since it gives rise to bone progenitor tissues, which in turn are subjected to the influence of diverse bone extracellular matrices and peptide growth factors. We proposed that the developmental history of this palate tissue is a highly instructive design template for the discovery of novel bioengineering tools and approaches [10].

Further developments will include a formulation for clinical applications. This formulation has to be based on scaffolds or delivery systems, which will be developed during the further research process of our defect model using the Osteoporotic Sheep. This will lead to the therapy of previously untreatable cases of facial defects and of advanced alveolar bone loss.

Acknowledgments. We would like to thank Darius Widera (University of Reading) and Frank Witte (CharitéUniversity Medicine Berlin, Julius Wolff Institute and Center for Musculoskeletal Surgery, Berlin-Brandenburg, Center for Regenerative Therapies) for their valuable support in cell culturing of ovine NCSCs and in the histological analysis of the alveolar bone using our Osteoporotic Sheep Model. This research was funded by the Stavropol State Medical University.

9. Keeve P. L., Dittmar T., Gassmann G., Grimm W.-D Characterization and analysis of migration patterns of dentospheres derived from periodontal tissue and the palate. J Periodontal Res. 2013;48(3):276-285

10. Kharazi A., Levy M. L., Visperas M. C. Chicken embryonic brain: an in vivo model for verifying neural stem cell potency. Laboratory investigation. 2013.

11. Kharzinova V. R., Sermyagin A. A., Gladyr E. A. A Study of Applicability of SNP Chips Developed for Bovine and Ovine Species to Whole-Genome Analysis of Reindeer Rangifer tarandus. J Hered. 2015;106(6):758-761.

12. Király M., Porcsalmy B., Pataki A. Simultaneous PKC and CAMP activation induces differentiation of human dental pulp stem cells into functionally active neurons. Neurochem Int. 2009;55(5):323-332.

13. Miura M., Gronthos S., Zhao M. SHED: stem cells from human exfoliated deciduous teeth. Proc Natl Acad Sci USA, 2003;100:5807-5812.

14. Miletich I., Sharpe P. T. Neural crest contribution to mammalian tooth formation. Birth Defects Res C Embryo Today, 2004;72:200-212

15. Mitsiadis T. A., Cheraud Y., Sharpe P., Fontaine-Perus $J$. Development of teeth in chick embryos after mouse neural crest transplantations. Proc Natl Acad Sci USA 2003;100:6541-6545

16. Sauerbier S., Stubbe K., Maglione M. Mesenchymal stem cells and bovine bone mineral in sinus lift procedures-an experimental study in sheep. Tissue Engineering Part C Methods. 2010;16:1033-1039.

17. Seo B. M., Miura M., Gronthos S. Investigation of multipotent postnatal stem cells from human periodontal ligament. Lancet. 2004;364:149-155.

18. Sirak S. V., Sletov A. A., Ibragimov I. M. Vliyanie poristogo titana na osteogennyi potential kletok kostnogo mozga in vitro. (Impact of porous titanium on osteogenic potential of bone marrow cells in vitro.) Medical News of the North Caucasus. 2012;27(3):22-25. 
19. Sirak S. V., Sletov A. A., Pereverzev R. V. Eksperimentalnoe primenenie poristogo titana pri otkrytom sinus liftinge. (Experimental use of porous titanium at open sinus elevation). Palliativnaya meditsina $i$ reabilitatsyia - Palliative medicine and rehabilitation. 2012:1:55-57.

20. Sirak S. V., Shchetinin E. V., Sletov A. A. Subantralnaya augmentaciya poristim titanom v eksperimente i klinike (Subantral augmentation with porous titanium in the experiment and clinic). Stomatologiya - Stomatology. 2016:95(1):55-58.

21. Widera D., Zander C., Heidbreder M. et al. Adult palatum as a novel source of neural crest-related stem cells. Stem Cells 2009;27:1899-1910.

22. Widera D., Grimm W.-D., Moebius J. M. Highly efficient neural differentiation of human somatic stem cells, isolated by minimally invasive periodontal surgery. Stem Cells Dev. 2007;16:447-460.

About authors:

Grimm Wolf-D., Professor, MD, PhD, MSc, Department of Dental Medicine, Faculty of Health, University

of Witten/Herdecke, Germany; Department of Stomatology, Stavropol State Medical University, Russian Federation;

tel.: +49230252971; e-mail: prof_wolf.grimm@yahoo.de

Fritsch Tilman, MD, PhD, Professor of Implantology:

tel.: +498651/64622; e-mail: tilmanf@hotmail.com

Giesenhagen Bernd, MD, PhD, Professor of Implantology;

tel.: +49561/40085362; e-mail: b.giesenhagen@gmx.de

Marco Alexander, MD, msc, Implantologist;

tel.: +492339911160, fax: +492339911162; e-mail: team@ph-zahnaerzte.de

Aybazov Magomet, Doctor of Agricultural Science, Professor, Head of Department for Sheep Breeding; tel.: $+7(8652) 717033$

Adamchik Anatoly, Candidate of Medical Science, Associate Professor, Head of Dept Therapeutic Stomatology; tel.: +7(8652)370795; e-mail: adamchik1@mail.ru

\title{
PROPERTIES OF DEVELOPED NIOSOMAL FORMS OF ANTI-CANCER SUBSTANCES N-HYDROXY-2-(2-(NAPHTHALEN-2-YL)-1H-INDOL-3-YL)-2- PHENYLACETAMIDE IN TREATMENT OF GLIOBLASTOMA
}

\author{
Bazikov I. A. ${ }^{1}$, Aksenov A. V. ${ }^{2}$, Maltsev A. N. ${ }^{1}$, Selimov M. A. ${ }^{2}$, Kornienko A. V. ${ }^{3}$, \\ Aksenov N. A. ${ }^{2}$, Aksenova I. V. ${ }^{2}$, Bazikov F. I. ${ }^{4}$ \\ 1 Stavropol State Medical University, Russian Federation \\ 2 North-Caucasis Federal University, Stavropol, Russian Federation \\ 3 Texas State University, San Antonio, United States of America \\ ${ }^{4}$ Charles University, Prague, Czech Republic
}

\section{СВОЙСТВА РАЗРАБОТАННОЙ НИОСОМААЬНОЙ ФОРМЫ

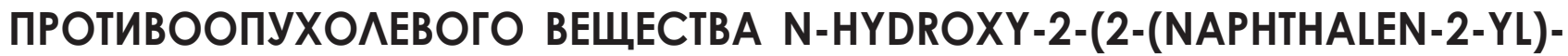 1H-INDOL-3-YL)-2-PHENYLACETAMIDE ААЯ АЕЧЕНИЯ ГАИОБААСТОМЫ}

\author{
И. А. Базиков ${ }^{1}$, А. В. Аксенов ${ }^{2}$, А. Н. Мальцев ${ }^{1}$, М. А. Селимов ${ }^{2}$, А. В. Корниенко \\ Н. А. Аксенов ${ }^{2}$, И. В. Аксенова ${ }^{2}$, Ф. И. Базиков 4 \\ ${ }^{1}$ Ставропольский госуаарственный меАицинский университет, Российская ФеАерация \\ 2 Северо-Кавказский фелеральный университет, Ставрополь, Российская ФеАерация \\ 3 Техасский госуаарственный университет, Сан-Антонио, США \\ ${ }^{4}$ Карлов университет, Прага, Чешская Республика
}

The physical properties of niosome form of anti-cancer substances Ax7 was studied. Samples of substances scanned in atomic forced microscope. Analyzing the results showed the middle size of niosomes with incapsulated antitumor substance is $100 \mathrm{~nm}$. Microviscosity of niosomes is low and elasticity is high, what ensures the passage of drug through the small capillaries and intercellular space. Silicone niosomes easily integrated into the plasma 